\title{
MULTICULTURAL EDUCATION IN SALAF PESANTREN AND PREVENTION OF RELIGIOUS RADICALISM IN INDONESIA
}

\author{
Marzuki*, Miftahuddin, Mukhamad Murdiono \\ Universitas Negeri Yogyakarta, Indonesia \\ *e-mail: marzuki@uny.ac.id
}

\begin{abstract}
Islamic boarding school (pesantren) is the oldest Islamic educational institution in Indonesia. Pesantren is recognized as one of the institutions that can encourage the realization of multiculturalism amongst Muslims. However, recently pesantren has been alleged to be one of the centers for the spread of religious radicalism. This study is aimed at analyzing multicultural education in salaf (traditional) pesantren, that is appropriate and be able to prevent the growth and development of religious radicalism in Indonesia. The study is a qualitative research with a phenomenological approach involving four salaf pesantrens in Java; namely Al-Qadir Pesantren of Sleman Yogyakarta, Dar al-Tauhid of Cirebon, Roudlatuth Thalibin of Rembang, and Tebuireng of Jombang. The research data were collected by observation, interviews, documentation, and focus-group discussions (FGD). Data were analyzed using an interactive technique. Findings showed that the forms of multicultural education at the four salaf pesantrens generally have similarities in the application of multiculturalism core values. However, each pesantren has its own specific peculiarities. The various cultures built up by the four caregivers of the salaf pesantrens have been effective to prevent the growth and development of religious radicalism at the pesantren, particularly, and in the society, more generally.
\end{abstract}

Keywords: religious radicalism, salaf pesantren, multicultural education

\section{PENDIDIKAN MULTIKULTURAL DI PESANTREN SALAF DAN PENCEGAHAN RADIKALISME AGAMA DI INDONESIA}

\begin{abstract}
Abstrak: Pesantren merupakan institusi pendidikan Islam tertua di Indonesia. Pesantren diakui sebagai salah satu institusi yang dapat mendorong terwujudnya multikulturalisme di kalangan umat Islam. Namun, akhir-akhir ini pesantren disinyalir menjadi salah satu pusat penyebaran paham radikalisme agama. Penelitian ini bertujuan menganalisis pendidikan multikultural di pesantren salaf (tradisional) yang mampu mencegah tumbuh dan berkembangnya radikalisme agama di Indonesia. Penelitian ini merupakan penelitian kualitatif dengan pendekatan fenomenologis yang mengambil setting empat pesantren salaf di Jawa Indonesia, yaitu Pesantren Al-Qadir Sleman Yogyakarta, Dar al-Tauhid Cirebon, Roudlatuth Thalibin Rembang, dan Tebuireng Jombang. Data penelitian dikumpulkan dengan pengamatan, wawancara, dokumentasi, dan focus group discussion (FGD). Analisis data menggunakan teknik analisis interaktif model. Hasil penelitian menunjukkan bahwa bentuk pendidikan multikultural di empat pesantren salaf secara umum memiliki kesamaan dalam penerapan core value multikulturalisme, meskipun setiap pesantren memiliki kekhasan masing-masing. Berbagai kultur yang dibangun oleh para kiai pengasuh di empat pesantren salaf tersebut terbukti efektif dalam mencegah tumbuh dan berkembangnya radikalisme agama di pesantren khususnya dan di masyarakat umumnya.
\end{abstract}

\section{Kata Kunci: radikalisme agama, pesantren salaf, pendidikan multikultural}

\section{INTRODUCTION}

Indonesia is a large country with the biggest number of Islam embracers in the world. Besides, Indonesia is also a country with a great diversity in various areas such as ethnicity, culture, language, and religion (Anshori, 2018). With its national pillars, Indonesia is able to retain its state and its national unity amidst the large existing diversities. These pillars of the nation are Pancasila, 1945 Constitution, Bhinneka Tunggal Ika, and the United State of the Republic of Indonesia. These four pillars become the glue and tie for the multicultural Indonesian state and nation (Samsuri \& Marzuki, 2016).

In line with the vast number of Islamic followers with its Islamic manifestation 
differences in Indonesia, there have come to surface various factions of the Moslem that polarizes into different streams and sects of religion. Differences in these streams and sects are marked by the differences in the ways the believers carry out their religious teaching and practices which then raise group sentiments and fanaticism. From here there emerge defenders of groups that often tend to overact leading to the claim that their groups are the rightest and that other groups are inferior, or even lost. In order to sustain the existence of the specificity of their stream and sect, these groups try to strengthen their positions by using religious arguments and indoctrinate their members so that they keep staying amidst the development of the existing thoughts. A certain number of the Moslem groups often take such an extreme measure in defending their groups that they do not hesitate to be radical and commit violence.

In a country where the majority of the population are Moslems, education becomes an important factor to ensure that the Islamic religion with all its teachings is guarded and inherited from generation to generation in a good way. It is for this purpose that education institutions are needed to facilitate the running of the Islamic learning. The oldest institution that is built to fulfill this function is the pesantren (Islamic boarding school) with all its forms and variations. In the colonilizaton era, pesantren has the main role as the centre of Islamic education in Indonesia with all its other roles and functions (Qomar, 2002; Srimulyani, 2012; Maksum, 2015). Wahid, Suwendi, \& Zuhri (1999) maintains that the pesantren is present to respond to the social situations and conditions that tend to be faced with moral decadences. The presence of the pesantren is needed as an agent of change to release the society from moral degeneracy, invasion, and poverty. In the development, Moslem figures continue to build modern education institutions called madrasah, and also schools (Steenbrink, 1994).

The pesantren is characterized by the existence of an institution, led by a kiai (cleric) in a location with a mosque as the centre for the learning processes, facilitated with a boarding house for the santris (students) and a house for the cleric, and using the "yellow book" as the instructional manual. According to Bisri (2007), in addition to these physical characteristics, a pesantren is also marked with the full independence and loyalty of the santri to the kiai, which is often cynically called a cult or veneration.

Generally, there are two types of pesantren in the community: the salaf (traditional) and the khalaf (modern). The salaf pesantren is that which still holds traditional values and has the potentials for multicultural awareness. The khalaf pesantren, meanwhile, is that which does not hold tightly to the traditional values and that follows the development of modern educational institutions so that it often ignores multicultural values. In its further development, then, not a few pesantren salaf adopts the systems of the pesantren khalaf so that they become pesantren salaf which is khalaf, or mixed or integrated pesantren (Maksum, 2015). Dhofier (1994) identifies some characteristics of the salaf pesantren, especially in terms of the learning system and materials. A prominent characteristic is the use of the "yellow book" as the instructional material, techings written by clerics of the Syafi'iyah stream, on paper of the yellow colour. This is the formal teaching given in the salaf pesantren.

The local wisdom and rationality have so far been understood as the traditional custom of the pesantren. Accordingly, any concepts of development for the pesantren should departs from this traditions so that there will be no historical breakage (Dhofier, 1994; Qomar, 2002; Mohammad, 2010). It is this salaf pesantren that is regarded as continuing the tradition of the teachings of Walisongo that upholds the values of tolerences in the teachings of Islam (Basri, 2014).

The pesantren has experienced a rapid development dynamic so that a number of pesantrens have emerged in the line of the views and convictions of the teachers and clerics. From this phenomenon, there surface new pesantrens with all characteristics that far deviate from the mainstream teachings that used to be established and taught down by earlier Islamic Scholars with all the traditional and multicultural characteristics. These new pesantrens tend to be characterized as radical, exclusive, and intolerant (Ma'arif, 2011). The most recent information (2018) from the National Body of Terrorism Combat (BNPT) indicates the involvement of 19 pesantrens radical movements including the santris and teachers (Armenia, 2016). 
Generally, the pesantren has become an Islamic education centre that is able to bequeth reliable Islamic traditions from generation to generation. The pesantren is even acknowledged as one of the bodies that are able to support the realization of multiculturalism within the believers who uphold the values of tolerence and diversities. However, in flow with the advances of time, the pesantren has also experienced development in its roles and functions. This development cannot be separated from the perpectives and efforts from the part of the teachers and clerics. Teaching materials, for examples, are solely dependent on the decisions of the teachers as there is no prescribe curriculum to follow. Consequently, some pesantrens can then become the places of the transmission of teachings that deviate from the mainstream such as those that are radical and intolerent towards particular groups (Susanto, 2007; Darmadji, 2011; Masduqi, 2013; Kusmanto, Fauzi, \& Jamil, 2015).

The presence of mainstream pesantrens with traditional and multicultural characteristics becomes important to be discussed in line with the booming trends of radicalism in pesantrens. Radical movements in Islam are initially motivated by theological and ideological convictions represented by the Khawarij. They do not hesitate to claim that their group is the rightest and others are faulty or, even, sinful. The Wahabi sect in Saudi Arabia performs the same movement as the Khawarij did. From here, this group carries out radical actions that are full of violence such as murdering Moslems who are not of their group or belief stream (Salamé, 1997). In the modern era, the emergence of al-Qaidah ideologies commanded by Osama bin Laden indicates the strength of the radical ideological doctrines that trigger the emergence of other movements in other countries such as the ISIS (Islamic State of Iraq and Syria), IIS (Indonesia Islamic State), Jama'ah Islamiyah, and others (Mufid, 2013; Sasongkojati, 2016). Education in the pesantren must, therefore, coloured with features that uphold cultural diversities and varieties. It is in this connection that multicultural education must be developed in the pesantren for the instigation of inclusive, tolerant attitudes and behaviours that highly uphold peace.
Multicultural education is one that produces learners to have the characteristics of local wisdom and tolerance; it is important to run education that produces learners who have inclusive views. It is multicultural education that will develop citizens who have nationalistic values that will help defend the unity of the nation from disintegration threats. If realized in educational systems of the religious favours, multicultural education is believed to be able to help students to acquire moderate and inclusive thoughts. Developing societies of this characteristic is important for Indonesia whose population is multiethnic, multireligious, and plural. Multicultural education is appropriately given since the early ages of the students such as at the elementary education level (primary and junior secondary schools) so that students acquire inclusive and tolerant thoughts early in their development. Some studies show significant influences of the running of multicultural education treatment towards the avoidance of radicalistic thoughts (Bahruddin, Rosyadi, \& Edy, 2018). Studies on the growth of radicalism in the pesantrens and efforts to curb it have been presented in the early part of this writing.

The present study is aimed to describe how multicultural education is implemented in the salaf pesantren and to analyze how multicultural education in the salaf pesantren is able to prevent the growth and movement of religious radicalism in Indonesia. Compared to earlier studies, the present study attempts to look at one different type of multicultural education, the one that is implemented in salaf pesantrens of which one of the main goals is to prevent the growth of religious radicalism. It is expected that results of the study can be used as one stepping stone for educators, education institutions, and the government to implant multicultural values in religious education learning so that students will not be trapped into lines of thoughts that are radical, extreme, exclusive, and peace threatening.

\section{METHOD}

The study used a phenomenological approach. The issues of religious radicalism have become trending topics in various countries, including Indonesia. It is not free from the problems of religious radicalism so that this has become one of the points of attention for 
the Government of Indonesia to find solutions. From research (Armenia, 2016; Darmadji, 2011; Kusmanto et al., 2015; Susanto, 2007), it has been concluded that some pesantrens have become one of the places for the growth of radical religious radicalism in the Islamic teachings. It is from these grounds that the present study is intended to show that salaf pesantrens, that implement multicultural education, is able to prevent this religious radicalism.

The subjects of the study included kiais (clerics), ustazes (teachers), and santris (students) of four salaf pesantrens in Java, and some intellectual figures who have the backgrounds of pesantren education that still maintains the salaf characteristics. Since there are so many pesantrens spread all over Java, one was taken from each province considered as valid enough to represent the rest. In Yogyakarta Province, choice was given to Al-Qadir Pesantren located in the village of Tanjung Wukirsari, Cangkringan, Sleman Regency Yogyakarta; in East Java, Tebuireng Pesantren in Jombang Regency; in West Java, Dar al-Tauhid Pesantren in Cirebon City; and in Middle Java, Raudlatuth Thalibin Pesantren in Rembang Regency. The main informants in this study were caregivers in the four salaf pesantren, namely Masrur Akhmad M.Z., caregiver of Al-Qadir Pesantren, Husein Muhammad, one of the caregivers of Dar al-Tauhid Pesantren, one of administrators of Raudlatuth Thalibin Pesantren, and one of administrators of Tebuireng Pesantren.

Data were collected by observation, interviews, focused group discussions, (FGD), and documentation. The reseacher took the role as the main data collector devised with instrument guides for the observation, interview, focus group discussion. Data were verified for validity measures by way of cross-checking. Data analyses were carried out using the interactive model of qualitative analysis technique from Miles \& Huberman (1992). The steps taken are data collection, data reduction, data display, and data verification or drawing conclusions.

\section{FINDINGS AND DISCUSSION Findings}

In principle, a pesantren is a social religious institution functioning as an education venue for the Moslems to learn more about the religious knowledge and practices. There are four salaf pesantren to become the subjects of the study; namely Al-Qadir of Yogyakarta, Dar al-Tauhid of Cirebon, Raudlatuth Thalibin of Rembang, and Tebuireng of Jombang. The Al-Qadir Pesantren is located in the village of Wukirsari, the district of Cangkringan, the regency of Sleman, and the province of Yogyakarta. It is erected in 1990 by Masrur Akhmad, MZ. The pesantren posts the vision and responsibility of building the characters and morals of the society to become more Islamic.

As a salaf pesantren, the education system implemented in the Al-Qadir Pesantren of Yogyakarta maintains the salaf characteristics. The pesantren has not opened formal education systems running the curricula of the state or of the Ministry of Religious Affairs. It seems that they will never open formal education programs since there are many formal schools around such as primary schools, junior high schools, senior high schools, and even universities. Many of the santris, however, go to formal schools outside the pesantren. They go to an elementary school, junior high school, or senior high school nearby. Some of them go to the universities such as Islamic University "Sunan Kalijaga", Yogyakarta State University, and Gadjah Mada University. As characteristics of salaf pesantrens, the Al-Qadir pesantren uses the "yellow book" of various topics and levels as the main instructional modules. All the "yellow book" textbooks are taught by using the sorogan and bandongan systems. Up to the present time, the bandongan classes are still run by the kiai, Masrur Ahmad M.Z. on specific scheduled sessions. The learning of the bandongan system is carried out in halaqah formats in the main hall of the pesantren. The Al-Qadir Pesantren also runs sessions of memorizing the Koran.

The Dar al-Tauhid Pesantren is located in the village of Jungjang, the district of Arjawinangun, the regency of Cirebon. Erected by Sanawi bin Abdullah bin Muhammad Salabi, the pesantren has played a big role in maintaining harmony in the midst of the diverse communities in the vicinity (Manfaat, 2013). On the death of Sanawi bin Abdullah bin Muhammad Salabi, leadership was continued by his son, Ibnu Ubaidillah Syathori, planked by some kiais like Husein Muhammad, Ahsin Sakho, Khozin Nasuha, and Marzuki Wahid (Manfaat, 2013). Two of these kiais are productive in promoting 
pluralism and multiculturalism to build harmony in the community's life by writing articles and books. Muhammad maps various inequality of relations between men and women through a variety of references carefully and critically, in 2004 he presents material related to the arguments in the Qur'an and the hadith of the Prophet Muhammad that as a religion rahmatan lil al'alamin, Islam also respects women. In 2011, he studies how prominent Muslim scholars in the fields of kalam (theology), fiqh (law), and tasawuf (mysticism) understand and approach religion from different disciplinary angles, in a way that may be considered to go beyond mainstream religious discourse. Meanwhile, Wahid (1999) describes the dimensions of thought, especially in science, the tradition of the study of the traditional books, teaching methods, and the patterns of pesantren culture that are thick with multicultural problems. Moreover, he examines some of the roles and positions of the Compilation of Islamic Law in Indonesia before the state (New Order) both from the perspective of the formation strategy, material, implementation, and functions of law (Wahid, 2001) and the compilation of Islamic Law and Counter Legal Druft of Compilation of Islamic Law from the perspective of legal politics in Indonesia (Wahid, 2004).

In addition to running the salaf teaching, the Dar al-Tauhid also opens formal education programs. In practice, the education models come into two types, namely the sorogan and bandongan model and the classrooom model or madrasah stream with distinct levels and curricula. Nevertheless, all programs still belong to the salafi teaching since all materials still contain materials from the "Yellow Book". It is true that the madrasah stream has adopted modern education with classes and curricula that are distintive and directive. It is for this reason that this system is called a mixed model (between salaf and modern). The education systems in this pesantren can be categorized into: (1) purely salafi; learning is done through sorogan and bandongan, (2) salafi classical (or mixed); the learning of the "yellow book" is done by class levels of Madrasah Diniyyah of the Ibtidaiyah level, Tsanawiyah, Aliyah, and Ma'had 'Aly, and (3) formal model including Madrasah Aliyah Nusantara (curriculum from the Ministry of Religious Affairs), Junior High
School-Plus (curriculum from the Ministry of Education), Wathaniyah Kindergartens, Dar alTauhid Play Groups, Special School A (for the blind), and Special School B (for the deaf).

Raudlatuth Thalibin Pesantren in Rembang Regency is erected by Bisri Mustofa in 1945. Now, it is run by his son, A. Mustofa Bisri. The salaf characteristics of this pesantren are still adhered but, for the educational programs, it slightly adopts the modern system while the sorogan and bandongan are still conducted. By the term "modern" here is meant to be similar to the Cirebon Dar al-Tauhid, that is, the learning of the "yellow book" is conducted in classes with distinct class levels and curricula. This model is called Madrasah Diniah (Religious School). The class levels are I'dad (preparatory), divided into Grade 1 and Grade 2 and Tsanawiyah, divided into Grade 1, Grade 2 and Grade 3. The sorogan and bandongan learning model has been the initial system in this pesantren before it develops into the madrasah system. However, as time passes, the three systems (sorogan, bandongan, and madrasah) run symultaneously and complete each other for the perfection of the santris in mastering the "yellow book".

The Tebuireng Pesantren of Jombang, 118 years old now, is erected by Hasyim Asy'ari in 1899 and is now led by his grandson, Shalahuddin Wahid (2006 - now). Dynamics of its journey include changes of the leadership, policies, constructions of infrastructures and fcilitities, numbers of santris, and education systems. The change typology of this pesantren is mainly concerned with the education and learning systems. Initially of the salaf type, in its dynamics, the pesantren can no more be called as salaf at all. Besides still clinging to the salaf education system, it adopts and applies modern education systems. It is therefore appropriate that, now, the pesantren is categorized into a mixed or integrated pesantren (between salaf and khalaf). The mixed characteristics can be seen from the implementation of the sorogan and bandongan models, a salaf characteristic, and the learning of the "yellow book", the salaf material. Meanwhile, the khalaf or modern features can be seen from its classical format in the learning management and the madrasah (modern school) format. The modern characteristic of the education system can also be seen from the adoption of the curricula which 
come from the Ministry of Religious Affairs and Ministry of Education and Culture or the use of the of the instructional methods. The education systems applied by the pesantren are Madrasah Tsanawiyah Salafiyah Syafi'iyyah, Madrasah Aliyah Salafiyah Syafi'iyyah, Junior High School Wahid Hasyim A., Senior High School Wahid Hasyim A., Madrasah Mu'allimin, and Ma'had 'Aly Hasyim Asy'ari. These schools apply the same system and curriculum as other schools. The difference lies in the assertion of the instructional materials that are supplemented with substances from the "yellow book".

\section{Discussion}

This research is focused on the forms of multicultural education implemented in the salaf pesantren. At the beginning some of the characteristics of the salaf pesantren have been confirmed. Wahid (2010) notes that the main characteristic of the teaching in the salaf pesantren is the emphasis on the literal study on a certain book through the reading of the book followed by the reading of other sources.

The individualistic system in the traditional Moslem teaching is called the sorogan, given to individual santris who have mastered the reading of the Koran. The principle method in the traditional teaching in the pesantren is called bandongan or weton. This method consists in the grouping of the santris from 5 to 500 listening to the cleric instructor reading, translating, explaining, and, often, analyzing Islamic books in Arabic. Each santri looks at his book and makes note on words and ideas that are difficult for him. The bandongan group is also called halaqah which means a circle of students under the mentoring of a teacher (Dhofier, 1994; Qomar, 2002; Thoriqussu'ud, 2012; Junaidi, 2017; Laili, 2018).

Another specific characteristic of the salaf pesantren is the extent of the devotion of the santris to the kiai. This devotion materializes on the full respect and obedience to the teachers and the kiai, the diligence and perseverance in learning accompanied with restraining conducts such as fasting, and the belief in grace (Kersten, 2011; Zuhriy, 2011). This phenomenon raises the sentiment that devotion of the santris to the kiai is an over-action, feudalistic, cultistic, and others. This view is, however, according to Bisri (2007), too simplistic, wrongly generalized, incorrect, and discrediting the kiais who really are persons who live for the worship of God, and not for the sake of the praises from people. Bisri (2007) explains further that the pesantren belongs to the kiai. Santris come to the pesantren to live by themselves. There are even santris who come and live under the expenses paid by the kiai. It can be said that the salaf kiai devotes his life for the welfare of the santris. The kiai takes care of the santris, educate them, teach them, and pray for their welfare without any expectation of rewards; not only while the santris are in the pesantren, but also long after they plunge into the community lives.

One of the salaf pesantren studied was AlQadir Pesantren Tanjung Wukirsari Cangkringan Sleman Yogyakarta. Islamic teachings that are taught in the Al-Qadir Pesantren are those that are friendly, contextual, and appreciative of multicultural values that are in line with Islam traditions. Masrur Akhmad MZ., as leader of the pesantren, is fully knowledgable of how Islam teahings should be delivered in the place where he teaches the religion. Masrur takes into account the reality that the sociery around the pesantren are fond of Javanese cultures such as leather puppet shows, jatilan performances, campursari orchestra, ketoprak folk plays, and other traditional performing arts. The delivery models of the religious teachings are, therefore, similar to those of the Walisongo's such as in the use of the stagings and festivals of ketopraks, music concerts, musabaqah tahlilan, campursari, shadow puppet, and jatilan. These activities take the involvement of the members of the communities and become the media of communication between the society members and the pesantren bring the them to the teachings of Islam (Mas'udi, 2015; Kholid, 2016; Luthfi, 2016; Rofiq, 2017; Zuhdi, 2012).

Since its establishment, the Al-Qadir Pesantren has never differentiated santris on the basis of origins, ethnics, languages, and socioeconomic backgrounds. There is only one factor that must be fulfilled, namely believing in Islam. What has been going in the pesantren becomes a true evidence that the pesantren is able to preserve the santris' differences in their cultures and give services the communities living around the pesantren.

In the present-day concepts, it can be said that the pesantren has sown seeds of strong 
multiculturalist education. The pesantren is built for the needs of people at large, without discriminating differences in their backgrounds. The word multiculturalism is derived from the morphemes multi- (many), culture, and -ism (ideology). Etymologically, it carries the meaning of the acknowledgement of the nature of human beings who live within their communities with their own unique cultures. Thus, every individual feels that they are being respected and having the responsibility to respect others in their community. The refusal of acknowledging one's needs is a root of discrimination of all kinds (Mahfud, 2009).

In Dar al-Tauhid Pesantren Marzuki Wahid and Husein Muhammad have given ideas and perspectives on the development of multicultural values in their santris whic has become valuable learning to them. In this case, the pesantren has, directly or indirectly, given the santris the learning to be different, accept differences, and have democratic and tolerant attitudes. By being able to accept differences in ideas, they are expected to understand wider diversities in religions, languages, ethnics, groups, and needs. The presence of santris from various regions suh as Medan, Jambi, Palembang, Lampung, East Nusa Tenggara, Indramayu, Brebes, and others is alone a feature in diversities. The phenomenon of the emergence of Islamic scholars called "liberalists" in the Dar al-Tauhid Pesantren is an interesting fact to discuss. The thoughts of Husein Muhammad and Marzuki Wahid that, in reality, can be said to deviate from the mainstream cultures of the pesantren have been responded upon by the pesantren, both by the santris and by the teachers; the chief kiai, Ibnu Ubaidillah, has seen it as an ordinary discourse. It is clear that balance can be seen in this pesantren; on one side, the kiai still cultivates the salaf thoughts and traditions of the teachers while, on the other side, he tends to take a moderate stance and other kiais, such as Husein Muhammad and Marzuki Wahid, can be said to have adopted the thoughts of modern scholars that can be said to be liberal (Muhammad, 2001; Muhammad \& el-Qum, 2011; Wahid, Suwendi, \& Zuhri, 1999; Manfaat, 2013; Wahid, 2014). Interaction can be seen, here, of different thoughts that will be beneficial to valuable culture and learning for the understanding of multiculturalism for all, both for the santris and for the teachers. Husein is on the same opinion with the idea that there are a personal space and a public space in the life of the community at large. Matters of faith and worships strictly personal to be accounted for to Allah himself, vertically. Meanwhile, the stances of Marzuki Wahid, as one of the Supervising Body of thesre not far apart from those of Husein Muhammad's.

The Raudlatuth Thalibin Pesantren, now headed by Mustofa Bisri, also promotes the intention for the santris, in particular, and community members. In general, to understand Islam in a kaffah ways, Islam that is inclusive, and Islam that accepts multicultural values. This is well-reflected in Mustofa Bisri himself, a kiai who has a vast perspective of Islam, from his thoughts that have been communicated in various moments. The cleris's inclusive ideas can be seen from many of his statements. If even by love and affection it is hard for the Prophet, Rasulullah saw., to accept his true teachings of faiths, he says, how would force and hate do that (Bisri, 2007). He further states that for Moslems, who expect to lead people to the true ways of Allah and to uphold His religion, there is no better way than following what Prophet Muhammad saw. does. It is not something too difficult to follow the footsteps of the Prophet for those who really understand people who humanize people (Bisri, 2007). On the other side, he further emphasizes, the formalization of Islam has been practiced by those who are radical and exclusive so that religion becomes an ideology whose conceptualizations are defined by particular political motivations (Bisri, 2010). A lot of the thoughts of Mustofa Bisri has also been revealed from his literary works through his many poems. His poetic works have been become topics of academic studies of scholars and students alike in the universities. Safitri (2017) showed that Mustafa Bisri's preaching thoughts had a wide influence on the preaching in Indonesia and is considered as a preacher who nurtures the people to spread goodness with the right method considering that Indonesian society is dominated by materialists. He established himself as a soothing and humanist scholar and easily accepted by many circles in Indonesia, like K.H. Yahya C. Staquf (the grandson).

In the Tebuireng Pesantren, from various understandings of his writings, Shalahuddin Wahid, the present cleric of the pesantren, it 
is understood that he is one of the figures who advocates the importance of multicultural values. It is no wonder that his religious teaching one that is friendly and can be said to be "moderate Islam". All this can be seen from his writing in various mass media such as Republika, Kompas, Media Indonesia, and Suara Karya. His works have also been published in books such as Negeri di Balik Kabut Sejarah (November, 2001) (Country Behind Historical Mist), Mendengar Suara Rakyat (September 2001) (Listening to the Voice of the People), Menggagas Peran Politik NU (2002) (Analyzing Political Roles of NU), Basmi Korupsi, Jihad Akbar Bangsa Indonesia (Nopember 2003) (Eradicate Corruption, Big Struggle of the Indonesian Nation), Ikut Membangun Demokrasi, Pengalaman 55 Hari Menjadi Calon Wakil Presiden (Nopember 2004) (Taking Part in Democracy Building, 55-day Becoming Vicepresident Candidate). The views and thoughts of Shalahuddin Wahid are generally not different from those of his brother, Abdurrahman Wahid (Gus Dur), concerning Islam and the state. Both advocate inclusive thoughts that highly value openness and diversity (Rosyidin, 2015).

In various occasions, Shalahuddin Wahid states the importance of multicultural values to be practiced, especially in the life of the state and nation of Indonesia. In his opinion, Pancasila must become the paradigm in in the life of the state and nation. In Indonesia, the nationalism and Islamism are like the two sides of the same coin; one cannot be separated from the other. Multicultural education will give students understanding on the treasure of the Indonesian nation in the form of the existing diversity. Through multicultural education, there will be realized the continuing Indonesian generation who will understand each other and work together albeit the different backgrounds in ethnicity, language, culture, and religion. Multicultural values can be learned in direct ways from formal schools and madrasah diniyah by the application of the formal curricula. Meanwhile, indirectly, these values can be learned by the santris from the cultures and traditions of the pesantren such as the modelling of the leaders and teachers, presentations of performing arts, interaction among the santris, the developing socio-religious thoughts, discussions of religious matters, dialogues with people of different ideas and opinions, and multicultural learning after the death of Abdurrahman Wahid who is buried in the area of the Tebuireng Pesantren. Still in an indirect way, multicultural values can also be learned from studies of the "yellow book" practiced in the pesantren.

From the practices of the multicultural education in the four pesantrens, identification can be made on the development of the pesantren multicultural education that can be used as a stepping stone for the program by other pesantrens. Table 1 below illustrates variations in the forms of multicultural education in the four pesantrens.

Table 1. Forms of Multicultural Education in the Four Salaf Pesantren

\begin{tabular}{|c|c|c|}
\hline No. & Pesantrens & $\begin{array}{l}\text { Forms of Multicultural } \\
\text { Education }\end{array}$ \\
\hline 1. & $\begin{array}{l}\text { Al-Qadir } \\
\text { Pesantren of } \\
\text { Sleman }\end{array}$ & $\begin{array}{l}\text { - Respect for local culture } \\
\text { - Da'wah using culture } \\
\text { (art) }\end{array}$ \\
\hline 2. & $\begin{array}{l}\text { Dar al-Tauhid } \\
\text { Pesantren of } \\
\text { Cirebon }\end{array}$ & $\begin{array}{l}\text { - Respect for difference } \\
\text { - Upholding tolerance } \\
\text { - Teaching moderate } \\
\text { religion }\end{array}$ \\
\hline 3. & $\begin{array}{l}\text { Raudlatuth } \\
\text { Thalibin } \\
\text { Pesantren of } \\
\text { Rembang }\end{array}$ & $\begin{array}{l}\text { - Teaching inclusive Islam } \\
\text { - Teaching peaceful Islam }\end{array}$ \\
\hline 4. & $\begin{array}{l}\text { Tebuireng } \\
\text { Pesantren of } \\
\text { Jombang }\end{array}$ & $\begin{array}{l}\text { - Teaching moderate and } \\
\text { friendly Islam } \\
\text { - Teaching peaceful Islam } \\
\text { - Integrating the teachings } \\
\text { of Islam and Pancasila } \\
\text { - Respect for local culture }\end{array}$ \\
\hline
\end{tabular}

The variations in the forms of multicultural education in the four pesantrens can be explained as follows. 1) The development of multicultural education in the pesantren is highly influenced by the ideas and perspectives of the clerics; 2) Multicultural education in the pesantren is not taught through a specific subject matter course but through various situations, conditions, and practices that are plausible for the santris in peaceful ways without violence; 3 ) The learning method that is used to deliver the instructional materials must be of the inclusive approach that highly hold ups the spirit of rahmatan lil'alamin, and not of the exclusive and radical approach; 4) The Islamic teachings given in the salaf pesantren must be those of the kaffah nature including 
faith, behaviour, and attitude that are adaptive and not against the local traditions around the pesantren; 5) The teaching of the religious materials in the salaf pesantren must adopt the model used by Rasulullah saw. and Walisongo that is characterized as tender and appreciative of the local cultures; and 6) Multicultural education teaches differences, diversities, and tolerance. The pesantren teaches the santris Islam knowledge and practices of different streams; they must respect the differences including those of faiths and practices. The conditions of salaf pesantren like this are almost the same as those in modern pesantren such as Pondok Pesantren Modern Gontor Ponorogo, East Java (Rochmat, 2002).

Of the values and characters of multicultural education attributed to the four salaf pesantrens, there are at least four core values that characterize multicultural education; namely appreciation towards the presence of cultural plurality in the community life, acknowledgement of the nature and essence of human rights, development of responsibility in the world community, and development of responsibility in the earth planet (Tilaar, 2009). Other multicultural values developed in the salaf pesantren are those of differences, diversities, and openness (Ghosh $\&$ Galczynski, 2014). It is also equally true that multicultural education carries the perspectives that acknowledge political, social, and economic realities that are experienced by individuals in their complex interactions that are culturally diverse reflecting the importance of culture, race, gender, ethnicity, religion and socio-economic status. In a wide frame, multicultural education involves all santris without discriminating their groups in terms of gender, race, culture, ethnicity, social stratum, and religion (Mahfud, 2009).

The implanting and strengthening of multicultural education, according to Tilaar (2009), should not be given in a specific separate lesson subject; instead, it must be integrated in relevant existing subjects such as social science education, language, civics, and moral education. Multicultural education is more appropriately treated as a learning process; in other words, it is a further development of the pluralistic culture in the environment of the school as a community body.

In Islamic perspectives, multicultural education cannot be detached from a pluralistic concept so there emerges the term pluralist-multicultural Islam. This educational construction is built on the orientation of the process of initializing the awareness of religious pluralistic and religious multicultural. In a further extension, the education construction of pluralistmulticultural Islam can be positioned as part of a comprehensive and systemic effort to prevent ethnic-religious conflicts, religious radicalism, separatism, and national disintegration. The basic value of this education concept is tolerance (Naim \& Sauqi, 2008).

The estuary of multicultural education is the growth of multiculturalism in the santris. Multiculturalism is an ideology that highly holds up cultural differences and a belief in the cultural pluralism as a texture of the society life. Multiculturalism becomes a bridge which will accommodate ethnic and cultural differences within the plural society (Broto, 2010). In the views of Islam, being plural and diverse is sunnatullah, the wish of God. It is accepted that the phenomenon of differences in religions and cultures of human beings from ancient time to now has been a fact that cannot be refuted. Diversities in religions and cultures can be expressed as religious and cultural pluralism. Meanwhile, the Koran is a holy scripture that has from the start described diversity as observable by vision as it is part of the unity of the creation of Allah (Ma'arif, 2009). In Islam, there truly is only one referential source; the Koran and Hadith; however, in phenomena, there are many faces of Islam. There are truly various groups and streams of Islam who have distinct characteristics from each other and who carry differences in their religious practices.

Multiculturalism in Islam has made this religion open and tolerant so that it is able to separate the believers from claims of truths that tend to be radical. This is one of the characteristics of inclusive Islam that is open to diversities of other believers based on the views that the other religions are world religions that bring goodness to their believers. In addition, inclusive Islam does not only show the realities of pluralism, but it also places active involvement in pluralism. On the other hand, exclusivism carries an attitude that views the faith, ideas, thoughts, and practices are the rightest while those of others are false, sinful, and must be avoided (Wijdan et al., 2007). 
After the Indonesian reformation period, it seems that radical religious movements appear to find the momentum to grow. Meanwhile, the groups and streams that practice traditional Islam rooted in the salaf pesantren tend to be close to the inclusive attitude, though not all. This inclusivism now tends to develop within these groups, especially in the circle of the youth since they have academic and pesantren education backgrounds. These groups are regarded as traditional Moslems since, their religious practices, they take Walisongo as their model. Walisongo, whose orientation is the Prophet Muhammad saw., becomes the direction of the santris (Sholeh, 2007; Mas'udi, 2015; Kholid, 2016; Zuhdi, 2012).

The emergence of radicalist movements in Indonesia are not solely prompted by theological or ideological matters, but they are also caused by other factors such as poverty, corruption, and globalization. Political turmoils and social deprivations also give shares in the polarization of religious intolerant undertakings (Mukodi, 2015). Rokhmad (2012) even comes to a conclusion that the growth and development of this radicalist movement are also advocated by activities of Moslem religious organizations in schools, materials of the religious education, and similar activities and instructional contents in the universities. Other studies also find empirical evidences that radicalist convictions develop in the vicinity of the university campuses due to the presence of many presentations and discussions carried out by radicalist Moslem groups in the university (Rijal, 2017). Therefore, in order to curb and, simultaneously, cut off the roots of this radicalism, each of the triggering variables must be eliminated and active efforts must be carried out for the running of religious education that is detached from radicalism and exclusivism.

The multicultural education practices carried out in the four salaf pesantrens are quite effective in giving the perspectives of Islam inclusivism to the santris so that they acquire the attitudes that are open and tolerant towards differences in streams, sects, and even religions. It is this type of multicultural education that is expected to be able to curb the growth and development of religious radicalism in Indonesia in which the seed beds have begun to be identified (Rohadi, 2017; Arifin, 2016; Raihani, 2012; Jamhari, 2003).

\section{CONCLUSION}

The existence of salaf (traditional) pesantren that highly holds up multicultural values is in concordance with Indonesian cultures since Indonesia is built of societies diverse in religions, ethnics, and cultures. This condition has been shown and practiced in the four salaf pesantrens of the study. It is a good example of the implementation of multicultural education in the pesantren.

The formats and models of the multicultural education practiced in the pesantrens are varied. However, the four pesantrens have something in common. They highly hold up multicultural values. The practice of multicultural education in the four pesantrens is closely tied to the role of the cleric as the main actor in the program. The cleric's ideas and perspectives of inclusive, moderate, tolerant, and harmonious Islam brings the pesantren and santris to the Moslem religion which is friendly and rahmatan lil'alamin, giving grace to all beings, not that which is radical and stiff to embracers of other religions nor to cultures that develop in the vicinity of the pesantrens.

With the pesantren cultures that are gurded by the cleric, it will be hard for radical religious ideologies to grow and develop amongst the santris. The multicultural education practices that are implemented in the four pesantrens have shown to be able to constraint the growth and development of religious radicalism in the pesantren as well as in the midst of the society.

\section{REFERENCES}

Anshori, A. G. (2018). Hukum perjanjian Islam di Indonesia: Konsep, regulasi, dan implementasi. [Islamic treaty law in Indonesia: concept, regulation and implementation]. Yogyakarta: Gadjah Mada Press.

Arifin, S. (2016). Islamic religious education and radicalism in Indonesia: Strategy of de-radicalization through strengthening the living values education. Indonesian Journal of Islam and Muslim Societies, 6(1), 93-126. doi:10.18326/ ijims.v6i1.93-126. 
Armenia, R. (2016, February 4). 19 Pesantren terindikasi ajarkan radikalisme. [Pesantren are indicated to teach radicalism]. CNN Indonesia. https://www.cnnindonesia.com/ nasional/20160203201841-20-108711/ bnpt-19-pesantren-terindikasi-ajarkanradikalisme.

Bahruddin, E., Rosyadi, A. R., \& Edy, E. (2018). Persepsi siswa madrasah tsanawiyah terhadap pendidikan multikultural keagamaan dalam penanggulangan radikalisme secara dini. [Madrasah tsanawiyah students' perceptions of religious multicultural education in tackling radicalism early]. Edukasi Islami: Jurnal Pendidikan Islam, 7(2), 179-194. doi: 10.30868/ei.v7i2.271.

Basri, H. H. (2014). Keragaman orientasi pendidikan di pesantren. [Diversity of educational orientation in pesantren]. Dialog: Jurnal Penelitian dan Kajian Keagamaan, 37(2), 209-220. http:// jurnaldialog.abuporsolutions.com/index. php/dialog/article/view/67/44.

Bisri, M. (2010). Koridor renungan A. Mustofa Bisri. [Reflection corridor A. Mustofa Bisri]. Jakarta: Kompas.

Bisri, M. (2007, Juli-September). Pesantren dan pendidikan. [Pesantren and education]. Tebuireng, Edisi 1/Tahun I.

Broto, A. L. (2010, January 10). Pluralisme dan multikultural. [Pluralism and multiculturalism]. Kompasiana. https:// www.kompasiana.com/anjrah_lelono broto/54ff50ada33311ad4c50 fbaa/ pluralisme-dan-multikultural.

Darmadji, A. (2011). Pondok pesantren dan deradikalisasi Islam di Indonesia. [Pesantren and Islamic de-radicalization in Indonesia]. Millah: Jurnal Studi Agama, 11(1), 235-252. doi:10.20885/ millah.vol11.iss1.art12.
Dhofier, Z. (1994). Tradisi pesantren: Studi tentang pandangan hidup kyai. [The tradition of pesantren: The study of the clerics' outlook on life]. Jakarta, Indonesia: LP3ES.

Ghosh, R., \& Galczynski, M. (2014). Redefining multicultural education: Inclusion and the right to be different. Toronto: Canadian Scholars' Press.

Jamhari, J. (2003). Mapping radical Islam in Indonesia. Studia Islamika, 10(3), 1-28. doi:10.15408/sdi.v10i3.622.

Junaidi, K. (2017). Sistem pendidikan pondok pesantren di Indonesia: Suatu kajian sistem kurikulum di Pondok Pesantren Lirboyo. [Pesantren education system in Indonesia: A study of the curriculum system at Lirboyo Islamic Boarding School]. ISTAWA, 2(1), 95-100. doi:10.24269/ijpi.v2i1.364.

Kersten, C. (2011). Cosmopolitan muslim intellectuals and the mediation of cultural Islam in Indonesia. Comparative Islamic Studies, 7(1-2), 105-136. doi:10.1558/cis. v7i1-2.105.

Kholid, A. I. (2016). Walisongo: Eksistensi dan perannya dalam Islamisasi dan implikasinya terhadap munculnya tradisitradisi di tanah Jawa. [Walisongo: Its existence and role in Islamization and its implications for the emergence of traditions in the land of Java]. JURNAL TAMADDUN, 1(1), 1-47. doi:10.24235/ tamaddun.v1i1.934.g684.

Kusmanto, T. Y., Fauzi, M., \& Jamil, M. M. (2015). Dialektika radikalisme dan anti radikalisme di pesantren. [The dialectics of radicalism and anti-radicalism in pesantren]. Walisongo: Jurnal Penelitian Sosial Keagamaan, 23(1), 27-50. doi:10.21580/ws.23.1.221.

Laili, K. (2018). Metode pengajaran di pesantren dan perkembangannya. [Teaching methods in pesantren and their 
development]. Al Iman: Jurnal Keislaman dan Kemasyarakatan, 2(1), 390-406. http://ejournal.kopertais4.or.id/madura/ index.php/aliman/article/view/3197/2368.

Luthfi, K. M. (2016). Islam nusantara: Relasi Islam dan budaya lokal. [Nusantara Islam: Relations between Islam and local culture]. SHAHIH: Journal of Islamicate Multidisciplinary, 1(1), 1-12. doi:10.22515/shahih.v1i1.53.

Ma'arif, A. S. (2009). Islam dalam bingkai keindonesiaan dan kemanusiaan: Sebuah refleksi sejarah. [Islam in the frame of Indonesianity and humanity: A reflection of history]. Bandung: Mizan.

Ma'arif, S. (2011). Dinamika pesantren kontemporer. [The dynamics of contemporary pesantren]. Millah: Jurnal Studi Agama, 11(1), 29-49. doi:10.20885/ millah.vol11.iss1.art2.

Mahfud, C. (2009). Pendidikan multikultural. [Multicultural education]. Yogyakarta: Pustaka Pelajar.

Maksum, A. (2015). Model pendidikan toleransi di pesantren modern dan salaf. [Model of tolerance education in modern pesantren and salaf]. Jurnal Pendidikan Agama Islam (Journal of Islamic Education Studies), 3(1), 81-108. doi:10.15642/ jpai.2015.3.1.81-108.

Manfaat, B. (2013). Praktik pendidikan multikultural di Pondok Pesantren Dar al-Tauhid Cirebon. [The practice of multicultural education in the Pesantren Dar al-Tauhid Cirebon]. Holistik, 14(1), 35-54. doi:10.24235/holistik.v14i1.161.

Masduqi, I. (2013). Deradikalisasi pendidikan Islam berbasis khazanah pesantren. [Deradicalization of Islamic education based on the pesantren]. Jurnal Pendidikan Islam, 2(1), 1-20. doi:10.14421/ jpi.2013.21.1-20.
Mas'udi, M. U. (2015). Dakwah nusantara: Kerangka harmonis dakwah Walisongo dalam diseminasi ajaran Islam di Nusantara. [Nusantara da'wah: A harmonious framework of Walisongo propaganda in the dissemination of Islamic teachings in the archipelago]. $A T$ TABSYIR STAIN Kudus, 3(2), 279-298. doi:10.21043/at-tabsyir.v3i2.1648.

Miles, M. B. \& Huberman, A. M. (1992). An expanded sourcebook qualitative data analysis (2nd ed.). California, CA: Sage Publications.

Mohammad, J. (2010). Pesantren dan pendidikan multikulturalisme. [Pesantren and multicultural education]. http:// buntetpesantren.org/index.php.

Mufid, A. S. I. (2013). Radikalisme dan terorisme agama, sebab dan upaya pencegahan. [Religious radicalism and terrorism, causes and prevention efforts]. Harmoni, 12(1), 7-17. http://jurnalharmoni.kemenag.go.id/ index.php/harmoni/article/view/190/159.

Muhammad, H. (2001). Fiqh perempuan: Refleksi kiai atas wacana agama dan gender. [Fiqh of women: Reflections on scholars for religious and gender discourse]. Yogyakarta: LKiS.

Muhammad, H. (2004). Islam agama ramah perempuan: Pembelaan kiai pesantren. [Islam-friendly religion: The defense of boarding schools]. Yogyakarta: LKiS.

Muhammad,H. \& el-Qum, M.A. (2011). Mengaji pluralisme kepada mahaguru pencerahan. [The study of pluralism on enlightenment majors]. Bandung: Penerbit Mizan.

Mukodi. (2015). Pondok pesantren dan upaya deradikalisasi agama. [Pesantren and religious deradicalization efforts]. Walisongo: Jurnal Penelitian Sosial Keagamaan, 23(1), 89-112. doi:10.21580/ ws.23.1.224. 
Naim, N. \& Sauqi, A. (2008). Pendidikan multikultural: Konsep dan aplikasi. [Multicultural education: Concepts and applications]. Yogyakarta: Ar-Ruzz Media.

Qomar, M. (2002). Pesantren: Dari transformasi metodologi menuju demokratisasi institusi. [Pesantren: From methodology transformation to institution democratization]. Surabaya: Erlangga.

Raihani. (2012). Report on multicultural education in pesantren. Compare: $A$ Journal of Comparative and International Education, 42(4), 585-605. doi:10.1080/0 3057925.2012 .672255 .

Rijal, S. (2017). Radikalisme kaum muda Islam terdidik di Makassar. [Radicalism of educated muslim youth in Makassar]. AlQalam, 23(2), 335-345. doi: 10.31969/alq. v23i2.434.

Rochmat, S. (2002). Dinamika Pondok Pesantren Gontor dalam modernisasi. [The dynamics of the Pesantren Gontor in modernization]. Jurnal Penelitian Humaniora, 7(2), 2746. https://journal.uny.ac.id/index.php/ humaniora/article/view/5469/4759.

Rofiq, A. C. (2017). Dakwah kultural Bathoro Katong di Ponorogo. [The Da'wah cultural Bathoro Katong in Ponorogo]. ISLAMUNA: Jurnal Studi Islam, 4(2), 304-316. doi: 10.19105/ islamuna.v4i2.1593.

Rohadi, T. (2017). Deradicalization through multicultural and local wisdom literacies based teaching model at salaf and kholaf pesantren in West Java. Ijtimā'iyya: Journal of Muslim Society Research, 2(1), 21-42. doi:10.24090/ijtimaiyya. v2i1.1050.

Rokhmad, A. (2012). Radikalisme Islam dan upaya deradikalisasi paham radikal. [Islamic radicalism and efforts to deradicalize radicalism]. Walisongo: Jurnal Penelitian Sosial Keagamaan, 20(1), 79-114. doi: 10.21580/ws.20.1.185.
Rosyidin, M. A. (2015, January 21). Biografi pengasuh Pesantren Tebuireng periode ketujuh K.H. Salahuddin Wahid (2006-sekarang). [Biography of the caregiver of Pesantren Tebuireng for the seventh period K.H. Salahuddin Wahid (2006-present)]. Tebuireng Media Group. https://tebuireng.online/kh-salahuddinwahid/.

Safitri, P. N. (2017). Studi pemikiran dakwah KH. Mustofa Bisri dalam buku Membuka Pintu Langit (Doctoral dissertation, UIN Walisongo). [Study of missionary thought KH. Mustofa Bisri in the Opening the Door of Heaven book]. http://eprints. walisongo.ac.id/id/eprint/7109.

Salamé, G. (1997). Islam and Politics in Saudi Arabia. Arab Studies Quarterly, 9(3), 306-326. https://www.jstor.org/ stable/41857933.

Samsuri, S. \& Marzuki, M. (2016). Pembentukan karakter kewargaan multikultural dalam program kurikuler di madrasah aliyah se-Daerah Istimewa Yogyakarta. [The formation of the character of multicultural citizenship in the curricular program in madrasas aliyah throughout Yogyakarta Special Region]. Cakrawala Pendidikan, 35(1), 24-32. doi:10.21831/cp.v1i1.8362.

Sasongkojati, A. (2016). Countering Islamic radicalization Indonesian experiences. (Technical Report No. AD1037659). Air War College, Air University Maxwell AFB United States. https://apps.dtic.mil/ dtic/tr/fulltext/u2/1037659.pdf.

Sholeh, B. (Ed.). Budaya damai komunitas pesantren. [The peaceful culture of the pesantren community]. Jakarta: LP3ES.

Srimulyani, E. (2012). Women from traditional Islamic educational institutions in Indonesia: Negotiating public spaces. Amsterdam: Amsterdam University Press.

Steenbrink, K. A. (1994). Pesantren, madrasah, sekolah: Pendidikan Islam dalam kurun modern. [Pesantren, madrasah, school: 
Islamic education in the modern period]. (K. A. Steenbrink \& Abdurahman, Trans.). Jakarta: LP3ES. (Original work published 1986).

Susanto, E. (2007). Kemungkinan munculnya paham Islam radikal di "pondok pesantren". [The possibility of the emergence of radical Islam in "pondok pesantren"]. TADRIS: Jurnal Pendidikan Islam, 2(1), 1-19. doi:10.19105/jpi. v2i1.205.

Thoriqussu'ud, M. (2012). Model-model pengembangan kajian Kitab Kuning di pondok pesantren. [Models for the development of the study of the Kitab Kuning in pesantren]. Jurnal Ilmu Tarbiyah" At-Tajdid, 1(2), 226-239. https://www.ingentaconnect.com/.

Tilaar, H. A. R. (2009). Kekuasaan dan pendidikan: Manajemen pendidikan nasional dalam pusaran kekuasaan. [Power and education: Management of national education in the vortex of power]. Jakarta: Rineka Cipta.

Wahid, A. (2010). Menggerakkan tradisi. [Trigger the tradition]. Yogyakarta: LKiS.

Wahid, M. (2001). Fiqh Madzhab negara: Kritik atas politik hukum Islam di Indonesia. [State Fiqh Madzhab: Criticism of the politics of Islamic law in Indonesia]. Yogyakarta: LKiS.
Wahid, M. (2014). Fiqh Indonesia: Kompilasi hukum Islam dan counter legal draft kompilasi hukum Islam dalam bingkai politik hukum Indonesia. [Indonesian Fiqh: Compilation of Islamic law and counter legal draft compilation of Islamic law within the political framework of Indonesian law]. Cirebon: Institut Studi Islam Fahmina.

Wahid, M., Suwendi, \& Zuhri, S. (1999). Pesantren masa depan: Wacana pemberdayaan dan transformasi pesantren. [Future Islamic Boarding school: Discourse on empowerment and transformation of pesantren]. Bandung: Pustaka Hidayah.

Wijdan, A., et al. (2007). Pemikiran dan peradaban Islam. [Islamic thought and civilization]. Yogyakarta: Safiria Insania Press.

Zuhdi, M. H. (2012). Dakwah dan dialektika akulturasi budaya. [Da'wah and dialectics of cultural acculturation]. RELIGIA, 15(1), 46-64. doi:10.28918/religia.v15i1.122.

Zuhriy, M. S. (2011). Budaya pesantren dan pendidikan karakter pada pondok pesantren Salaf. [Pesantren culture and character education at the Salaf boarding school]. Walisongo: Jurnal Penelitian Sosial Keagamaan, 19(2), 287-310. doi:10.21580/ws.19.2.159. 